\section{Indian farmers burn transgenic cotton crop in field trial}

[NEW DELHI] Farmers protesting against genetically engineered crops last week destroyed a plot in the Raichur district of India where $B t$ cotton produced by the US company Monsanto was undergoing field trial.

Some 60 members of Karnataka State Farmers' Association, led by its president, M. D. Nanjundaswamy, uprooted the plants and burnt them. They described their action as "a message to all those who have invested in Monsanto to take their money and get out".

The plot is one of the 40 locations in India where the $B t$ cotton, which is resistant to bollworm, is being tested by Maharashtra Hybrid Seed Company, in which Monsanto has 26 per cent shares. Permission for the trials was given by the Department of Biotechnology (DBT), and the trials were expected to be concluded by end of 1999.

A DBT official, P. K. Ghosh, says destruction of the crop was unwarranted as the trial plots were being monitored by his department to check for escape of pollen. "The trials posed no biosafety concern and toxicity tests in animals showed the Bt cotton is perfectly safe and did not cause allergic reactions," according to Ghosh, who says that DBT was going to clear the crop for commercial production (see Nature 388, 817; 1997).

Four more crops - potato, tomato, cauliflower and tobacco - carrying the Bt gene are also undergoing field trials, and a highyielding transgenic mustard is being grown in 20 locations. According to Ghosh, all these crops will be ready for large-scale trials next year, subject to government clearance.

But critics such as Vandana Shiva, president of the Research Foundation for Science, Technology and Ecology, are calling for an immediate halt to Monsanto's trials and a five-year moratorium on the commercialization of genetically engineered crops while adequate ecological and regulatory frameworks are developed.

K.S.Jayaraman

\title{
Richter quits as director of Stanford accelerator lab
}

[WASHINGTON] Burt Richter, one of the most influential - and certainly the most colourful - of the directors of the Department of Energy laboratories, is to step down next August as director of the Stanford Linear Accelerator Center (SLAC) in California. He will remain at SLAC, however, working on research and science policy issues.

Richter, who won the 1976 Nobel Prize for Physics for his work at Stanford on developing a particle collider that led to the discovery of the $J / \varphi$ particle, became director of SLAC in 1984 when Wolfgang Panofsky retired. Even though he has been director of SLAC for 14 years, the unexpected departure of such a highly motivated scientific leader created a maelstrom of rumours, in California and Washington, about its true rationale. Stories that Richter had been forced out were dismissed by his former deputy, Sidney Drell, as "a load of nonsense".

Richter leaves SLAC in good shape, with the B-Factory, a new facility for producing $\mathrm{B}$-mesons, having been inaugurated in October, and an upgrade under way at the laboratory's synchrotron light source. But his departure leaves others to pursue his dream of building the Next Linear Collider (NLC), which many see as the world's next major particle physics accelerator, in California.

Richter had recently learned that the start of the conceptual design phase of the NLC will not be included in the Department of Energy's (DOE's) budget proposal for the year 2000. But he denies that his decision to step down was affected by this or by the most recent of his arguments with his superiors at the DOE - a row with Martha Krebs, the assistant energy secretary, and her boss at the time, Federico Peña, over the allocation of money for science education between the laboratories and DOE headquarters.

"I don't have any problem with the DOE," Richter told Nature last week. He added that

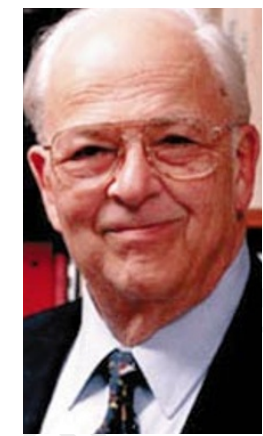

he had been thinking of stepping aside for a couple of years, and told Gerhard Casper, the president of Stanford University, of his decision in the summer. Richter points out that construction of the NLC is not due to begin until 2003 at the earliest. "The next generaRichter: denies rift tion should take care of with Washington. it now," he says, adding that he will still be director for another nine months, and intends to keep pursuing research to support the NLC.

Richter has vigorously pursued the idea of building the NLC somewhere in California - SLAC's site is too small to accommodate it - in close collaboration with Japan and other nations. But, according to one government official, Richter has not done enough to engage other US laboratories in the project, and the DOE would like to see more laboratories involved, partly to broaden its political support.

Despite his single-minded pursuit of SLAC's interests, Richter will be missed by other laboratory directors, who admired his chutzpah.

"He has been one of the best and most clear-thinking of the laboratory directors," says Bill Madia, director of the Pacific Northwest National Laboratory in Washington state. "There's no sugar-coating with Burt he calls it as he sees it."

Richter says that, although he has enjoyed supervising research at SLAC, other aspects of the job, which involved dealing with the world outside, "have been interesting but stressful. Your enthusiasm for it reaches a maximum and then begins to get exhausted. Then it is time to step down." ColinMacilwain

\section{Moscow scientists reject funding deal and plan more protests}

[Moscow] Scientists in Moscow have vowed to continue protesting at the lack of adequate funding for research, rejecting an agreement reached last month between the Russian Committee of Scientific Collectives (RCSC) and the deputy prime minister Vladimir Bulgak.

Although the government has, in line with the agreement, paid the scientists their salaries for November, a meeting of the trade unions of the Moscow branch of the Russian Academy of Sciences (RAS) issued a statement saying that they felt "free to break the achieved agreements" (see Nature 396, 208 ; 1998).

The researchers insist that, before the end of the year, the cabinet should transfer 5 billion rubles (US $\$ 28$ million) to scientific organizations, including 2.9 billion rubles in salaries. These figures were approved earlier this year by the previous government, which was dissolved in August.

But these figures are significantly higher than those in the agreement signed by the RCSC, which is the Russian trade union of scientific workers. This gives only 1.9 billion rubles, including 1.8 billion in scientists' salaries. The cabinet has promised to pay another 1.1 billion rubles to scientists in January and February next year, and the remaining 2 billion will be provided in exemptions from utility charges.

The Moscow RAS trade unions say that they cannot accept a situation in which there is virtually no money for scientific work itself, such as equipment, reagents, conferences and seminars. They are seeking the support of other regional branches for their position.
Carl Levitin 